\title{
China Pakistan Economic Corridor (CPEC); Most Valuable Dream for Pakistan through Economic Integration in the Region but May Not Become True without Upgradation of Physical Infrastructure and Legal System!
}

\author{
Rohimi Shapiee, Rao Qasim Idrees \\ Faculty of Law, National University of Malaysia, Bangi, Malaysia \\ Email:rohee@ukm.edu.my, qasim.rao@uog.edu.pk
}

How to cite this paper: Shapiee, R., \& Idrees, R. Q. (2017). China Pakistan Economic Corridor (CPEC); Most Valuable Dream for Pakistan through Economic Integration in the Region but May Not Become True without Upgradation of Physical Infrastructure and Legal System! Beijing Law Review, 8, 481-498.

https://doi.org/10.4236/blr.2017.84027

Received: September 19, 2017 Accepted: December 12, 2017 Published: December 15, 2017

Copyright $\odot 2017$ by authors and Scientific Research Publishing Inc. This work is licensed under the Creative Commons Attribution International License (CC BY 4.0).

http://creativecommons.org/licenses/by/4.0/

\begin{abstract}
To achieve the goal of sustainable economic development of Pakistan through logistics arrangements in CPEC, this research paper identifies and analyses benefits of CPEC, and also examines and highlights the legal system of Pakistan and its associated deficiencies in this context. Furthermore, this research paper critically examines the present logistics arrangement between China and Pakistan with reference to trade in services commitments and their impacts on such agreement. Governance, law and policy issues towards achieving Sustainable Development Goals (SDGs) are also big concerns for Pakistan. This will raise diverse legal and policy issues hence create uncertainty and conflict of laws both domestic and internationally. These issues can be handled and solved through upgrading domestic transport and logistics laws and making them in line with international practice. Furthermore coordination and cooperation between local institutes and agencies is most important initiative to gain maximum benefits. Adoption and accession of international conventions of transport and logistics will also have key role to play for better results from CPEC. The current research is rested on qualitative and sociolegal methods of research whereby the authors opt for a qualitative research design as opposed to a quantitative one. The research design would be the analysis between road transport and logistics investment laws exists in Pakistan and Chinese model of logistics arrangement formulated in CPEC by both countries. This research paper will discuss these in detail. Firstly, China Pakistan bilateral trade relations and impacts on Pakistan economy. Secondly, CPEC transport and logistics investment in physical infrastructure in Pakistan.
\end{abstract}


Thirdly, analysis of current rules and regulations applicable for China Pakistan bilateral trade and logistics arrangements. Fourthly, CPEC investment and future challenges for Pakistan and finally proposed comprehensive logistics investment framework agreement.

\section{Keywords}

China Pakistan Economic Corridor, Infrastructure; International Trade Law and Policy, Logistics and Transport, World Trade Organization

\section{Introduction}

Modern road logistics sector not only play an important role in boosting the economic activities in the country but also benefited from globalization through linked routes. Pakistan can harvest this opportunity due to its geographic position in the region through modern communication network. Most emerging economies of the world are transforming their economies towards transportation, storage and transit business (Ministry of Finance, 2014).

This research paper will highlight that the efficient transport and transit network is not only pre-requisite for economic development but plays a key role in economic integration of the country. This sector has direct and indirect links with all important sectors of the economy, which influence directly social and economic prosperity of the people. An efficient transport system contribute to economic growth by lowering production cost through timely delivery of raw materials of agriculture sector to the market and making timely delivery to manufacturing sector thus enhancing economies of scale in the production process and creating economic opportunities through communication links among domestic and cross border population. It directly provides sufficient employment opportunities to the lower class of the society, whom otherwise cannot find job opportunities due to lack of education (Khan, 2015).

It is evident that the vast road network spread over the country provides easy access to the regions consists upon hilly/mountain areas, far flung agriculture lands and natural/productive resources scattered all over the country. National highways provide easy and efficient means of transportation for moving goods from place to place and human being.

Furthermore current cross border investment and logistics arrangements throughout the world proposes a thematic change to the traditional definition of the "transport and logistics sector". Firstly, it will not be just confined to physical infrastructure such as roads and transport and related freight, but will also include services such as packaging, delivery, and storage and trade logistics (Vickerman, 2002). Secondly, factors like high freight, insurance, longer delivery times and renewal costs, will be considered as important additional costs, which require careful review. Thirdly, the aggregate transport and logistics costs including 
opportunity cost, service standards and trade facilitation ultimately determine the efficiency of the transport and logistics sector, and also represent the cost of doing business in Pakistan. Hence, these will be featured prominently in this paper, and a comprehensive but effective plan is being developed for this sector. This will help make the country and region more competitive economically, which is the central theme of the China Pakistan Economic Corridor (Mateen, 2015). To gain this momentum of logistics investment, a highly competitive and effective set of legal rules and regulations is direly required which does not only comprised on domestic legal regime but also provide transnational harmonized and integrated legal structure. Moreover, it is vastly foreseeable that CPEC not only will remain between China and Pakistan but also welcome other economic players in the region on an immense level.

\section{China Pakistan Bilateral Trade Relations and Impacts on Pakistan Economy}

Pakistan and China enjoy a cordial relationship over the years. The recent transfer of Gwadar Port by Pakistan to China under CPEC initiative should be seen in increasing trade and investment ties between the two countries and in the much larger economic perspective of South Asia and the Gulf. Furthermore due to mutual understanding and close diplomatic relations, their bilateral trade has been positively and highly increased over the years. Bilateral trade has crossed the barrier of nearly US\$ 12 billion by January 2013, which is expected to touch down the level of around US\$ 15 billion in coming years. This growth was the result of the Early Harvest Program, 2004 (EHP), Preferential Trade Agreement (PTA), Free Trade Agreement, 2006 (FTA), and various other favourable policy frameworks that have been adopted after 2005 when trade hovered around just US\$ 3 billion (Government of Pakistan, Trade and Development Authority, 2016). By 1980, bilateral trade has increased to US\$ 402 million and further it increased to US\$ 424 million by 1990 . Bilateral trade has not jumped to more than US\$ 722 million in 2000. By then in the next ten years, trade rose to US\$ 11 billion. Surprisingly, Pakistan exported goods worth US\$ 15 million in 1960. In the next fifteen years, exports were rather deteriorated and gone down to US\$ 14 million in 1975. Again in 1980, Pakistan's exports to China increased to US\$ 221 million but sharply declined to US\$ 67 million in 1990, instead of increase in this decade. During 2000-2010, exports have risen to US\$ 237 million to US\$ 1.5 billion. As far imports from China were concerned, they steadily increased from a meagre amount of US\$ 4 million in 1960 to as high as US\$ 9.2 billion by 2010 .

By 2010, Pakistan's trade deficit vis-à-vis China stood around US\$ 7.7 billion. China being the fourth largest economy of the world, with a trade surplus of $\$ 30$ billion and foreign exchange reserve of $\$ 1$ trillion, has strategically moved from being a centrally planned to a market based economy. At the end of 2006, China's global trade exceeded $\$ 1.758$ trillion. Pakistan in comparison is an emerging economy with nominal GDP of $\$ 128.5$ billion, a trade deficit of $\$ 8.51$ 
and foreign exchange reserves in excess of $\$ 13$ billion. Given the disparity in the sizes and economies of these two countries, entering into an FTA arrangement at this point in time can lead to some very crucial implications for both the countries, especially for Pakistan (Maher, Hussain, \& Ahmad, 2014).

The overall Foreign Direct Investment (FDI) in Pakistan has risen by over $600 \%$ in the last five years. However, the Chinese share in the overall FDI is still very low. Pakistan has been able to introduce and implement investor friendly policies as a result of which FDI has increased (Muhammad, Qi, \& Hamza, 2016). Pakistan's investment policy is very liberal which makes available all economic sectors for FDI. It provides equal treatment to local and foreign investors and allows $100 \%$ equity to foreign investors with no government sanction required. Full remittance of profits, capital, dividends, royalties, technical and franchise fees is allowed. Economic Effects of the Recently Signed Pak-China Free Trade Agreement 181 Complete legal cover is provided through Foreign Private Investment (Promotion \& Protection) Act 1976, Protection of Economic Reforms Act 1992, and Foreign Currency Accounts (Protection) Ordinance 2001.

Similarly, the Chinese government encourages foreign investment in the Chinese market, and has continuously liberalized and expanded the fields for investment. In recent years, China has further liberalized the restrictions imposed on the proportion of foreign equity in investment projects and opened new sectors to foreign investment.

In the context of CPEC, Chinese President signed MOUs and agreements for projects worth US\$ 46 billion during his visit to Pakistan in April, 2015. With bulk of these projects likely to be implemented during the next three years, it can be anticipated that this investment would likely have significant positive consequences for Pakistan's economic growth. Chinese investments can lift financial year 2016-18 GDP growth beyond 6\% through direct impact. The local component of this investment can be around US\$ 18 billion, assuming a higher local component for investments in hydel, road, rail, special economic zones and Gwadar Port (50\% to $80 \%$ ) and lower for Machinery intensive coal based power plants (20\%). This alone could add 2.1pp to GDP growth each year during financial year 2016-18 and could raise GDP growth above 6\% (Small, 2015).

This will be the primary object of this research to draw attention to CPEC logistics investment and frame the set of rules and regulations for transnational trade. Primarily CPEC marked a new phase in the development of the relationship by putting economic cooperation and connectivity squarely at the centre of the bilateral agenda between China and Pakistan. The aim of the CPEC is to cooperate in the planning and development and to facilitate and intensify economic activity along the corridor (Zafar, 2015).

The CPEC is being conceived as a lynchpin of the plans by the two countries to deepen their economic cooperation. Early implementation of the CPEC would be transformational for Pakistan's economy and dovetail perfectly with China's strategy of developing its inland and western regions. China's interest in the 
project is also strategically driven by President Xi Jinping's visionary concept of integrating regions and countries across the globe under the Silk Road Economic Belt and the 21st Century Maritime Silk Road Initiative. Most importantly it envisages deepening policy coordination amongst countries and regions, extending and improving transport infrastructure and connectivity in all its forms like road, air, rail, telecommunications, energy etc. across regions, fostering trade and investment flows, and, last but not the least, enhancing people to people connectivity. CPEC fits naturally into this vision of a 'Road and Belt' with Gwadar and Karachi serving as its southern nodes and an outlet to the Arabian Sea and the Persian Gulf.

Thus, China-Pakistan Economic Corridor will provide an integrating platform for over three billion people in Central West and South Asia, the Middle East and Africa Regions. The increase in trade, investment and financial flows would bring peace and prosperity to the region through enhancement in the competitiveness of the economies of the countries, contribute to reducing regional disparities and social inequality, and improve life expectancy and quality of life in every country and in the regions (China-Pakistan Institute, 2009).

For institutional arrangement and development of the CPEC, National Development and Reform Commission, China (NDRC) has constituted subsidiary Working Groups of the Joint Cooperation Committee (JCC-the Ministerial level apex body) on planning, transport infrastructure, energy and Gwadar for which they have nominated their respective lead agencies for this work. Accordingly, Working Groups in these areas have been constituted on Pakistani side as well.

In August, 2014, during 3rd meeting of JCC meeting 21 projects in the energy sector valuing US\$ 33.793 billion, 4 projects in the transport infrastructure sector valuing US\$ 9.784 billion and 8 projects for Gwadar valuing US\$ 0.793 billion were identified as early harvest prioritized projects (China Pakistan Economic Corridor Council, 2014).

An outline of the long term planning has been finalized containing on the basis of planning from the perspective of China and Pakistan, development goals, identifies key areas and major projects including spatial structure and functional zones, construction of an integrated transport system, IT connectivity, energy cooperation, industries and parks, agriculture development and poverty alleviation, cooperation in livelihood areas and people to people communications and financial cooperation.

\section{Significance and Achievements of CPEC for Pakistan}

Pakistan as a well beneficiary of CPEC, and has tremendous opportunity to overcome shortage of energy and give rise to poor economy conditions throughout country. It is to be noted that Pakistan has signed a currency swap with china in 2014 year, which results Pakistan the first South Asian nation to sign this kind of agreement with China. China is the second major trade partner of Pakistan and chief investor in infrastructure, telecommunications, ports, energy 
sectors. Furthermore, Chinese government and private companies from China have assured to spend US\$20 billion in the energy sector and huge amount of above $\$ 30$ billion in other sectors as a foreign direct investment in Pakistan. The current expansion and progress in China Pakistan Economic Corridor creates Pakistan the first passage centre for the world's second largest economy between the South Asian countries. Regardless of political and military objectives of this foremost project, it has various advantages for the people of the land. Furthermore, Pakistan is suffering from long back energy deficiency and limited trade with its conflicted neighbours, will be more strong geographically and self sufficient in energy sector. A Pakistan allied road and railway network will allow contacts between Pakistan's neighbours on west and east. India and Iran necessarily benefited through this corridor in faster cooperation with each other's economy. No doubt, CPEC abridge movement of goods and services in the whole region, China's input in the region's economy rotates opponents into business competitors with developing harmony and solidity in the South and Central Asian nations (Rizvi, 2015).

With regard to achievements of CPEC, the China Pakistan Economic Corridor is making significant progress as work rapidly continues on the four key areas of cooperation energy, transport and logistics infrastructure, industrial cooperation and Gwadar port. According to Russian news agency Sputnik in its report quoting a research report of Chongyang institute for financial studies at Renmin university of China, said the construction in these key areas was unexpectedly fast whereas electricity and infrastructure has been smooth for development. It further elaborates that over the past four years, the country has been through a period of stability and consequently the annual growth rate of Pakistan's economy has been constantly above 4 percent, making it one of the best performers in Asia. Hence the inflation rate has continued to decline, dropping below 2 percent and reaching the lowest point in 12 years (Associated Press of Pakistan, 2017).

\section{CPEC Gwadar Port, Highways Construction, Transport and Logistics Investment in Pakistan by China}

\subsection{Projects Relevant to Gwadar Port}

Gwadar has been considered as one of the Pivotal Points and Gwadar Port as Gateway of CPEC. Ten projects were approved by 2nd JCC (Feb 2014) as first stages EHPs, five more projects have been considered as second phase EHPs by 5 th JCC (Nov 2015). Tentative cost for all is over US\$ 2.500 billion. The completion time line is within the EHP, i.e. 3 - 5 years (Ministry of Ports and Shipping, Gwadar Port Authority, 2015).

$>$ Construction of Expressway on East Bay of Gwadar Port

> Type: 6-lane (Embankment) 04 Lane road at initial stage plus double track railway

Length: $18.9 \mathrm{~km}$ 
Off Shore (Coastline): $4.3 \mathrm{~km}$

On Shore: $14.6 \mathrm{~km}$

Bridge: 01

Box Culverts: 51

Cattle Creeps: 02

Pedestrian Bridges: 02

D The Executive Committee of the National Economic Council (ECNEC) the project at the Cost of Rs. 14,062 Million.

FEC Rs. 13,543 Million

Local Rs. 520 Million

Funding source is $100 \%$ interest free loan from Chinese Government

\subsection{Gwadar Port Free Zone}

Gwadar port free zone area is located near the port terminals, the coastal express way, the railway yard, and Makran Coastal Highway. This area is reserved for industries or businesses which would like to benefit from the tax exemption that is typical of these zones. Regime package will be competitive with international standards (e.g. Jebel Ali, Salala and Chahbahar).

It is also convenient in terms of land access and rail marshalling and inter-modal facilities being proposed. This area is equipped with major facilities such as warehousing, container freight station, re-packaging, processing plants, light manufacturing, and assembling goods. Gwadar port free zone area will be duty free and also customs and all types of taxes exempted. It will be constructed on BOT model by Chinese company (Ministry of Foreign Affairs, Government of Pakistan, 2013). The main features of free zone area are

Duty free

Free from customs interrogation

Tax free (Tax only on the goods sold in the local market or goods coming in from the local market)

General regulations by the Owner

$>$ BOT model

$>$ Operated by an experienced operator

Facilitation in storage of cargo without paying duties

$>$ Light manufacturing which helps in boosting manufacturing/assembling products with minimum cost

Contributing to local economy as engine of Industrial growth

Assisting in port productivity

No corporate income tax for 23 years

$>$ Reduced corporate income tax by $50 \%$ for 10 years after 23 years of tax break (Proposed)

$>100 \%$ exemption of customs duties on Import and exports of commodities and finished products for the purpose of export and re-export

No duties on machinery and raw material used in production 
Full repatriation of profits

Full repatriation of capital

$100 \%$ foreign ownership allowed

$>$ Tax Exemptions to Concession Holder

Broader exemptions are

Corporate income tax for 23 years

Income tax on interest income of loans acquired

$>$ Stamp duties on loans acquired

23 years tax holiday: all federal, provincial and local taxes, charges and levies

$>$ Import duties and sales tax on all imports for materials/equipment required for construction expansion and operations of Port for 40 years

Duties on ship bunkers oils

\subsection{Infrastructure and Highways Construction}

Sustainable economic development of Pakistan is dependent on a robust and low-cost transport and logistics sector. Enhanced export competitiveness also depends on the efficient performance of the sector. Despite economic slowdown, the sector has maintained positive growth trends. Signs of the economic recovery are already visible and the GDP growth rate is likely to rise further. In line with the country's expanding economic activity, the current levels of inland traffic by road and rail is estimated at 433 billion passengers-kilometre (BP-km) and 269 billion tonnes-km (BT-km) respectively is likely to increase to $614 \mathrm{BP}-\mathrm{km}$ and 381 BT-km by 2018 with huge flow of goods and passengers is expected as corridor is going to be operational. At present, the sector provides approximately three million jobs, and these are expected to increase to about 3.6 million during the initial corridor period (Benish, 2013).

The government is aware of the vital role of the sector in the overall economic development and in improving the competitiveness in exports. It is, therefore, committed to implement a comprehensive development initiative for modernising the sector through a continuous process of reform supported by focused investments in all of its sub sectors. The sector claims 25 to 30 per cent share of the annual Public Sector Development Programme (PSDP), but this level of investment is not enough to meet the growing needs. Approximately two to three times more investment is required to enable the sector to perform in harmony with the needs arising from the expansion of economic activities. Concerted efforts will, therefore, be made to promote the public private partnerships for leveraging higher investments from the private sector (Ministry of Planning, Development and Reform, 2016).

The following is the detail of huge Chinese logistics investment under CPEC for the construction and infrastructure of highways connecting to China border and within Pakistan.

$>$ Khuzdar-Basima Highway (N-30)

$>$ D. I. Khan-Quetta Highway (N-50) 
Establishment of Havelian Dry Port

KKH II (Havelian-Thakot)

Upgradation of ML-1

KKH III (Raikot-Thakot)

$>$ Optical Fiber Cable from Rawalpindi to Khunjrab

Karachi-Lahore Motorway (Sukkur-Multan)

\section{Current Legal System of Pakistan Related to CPEC Transport and Logistics Investment}

This part of research paper elaborates exclusive CPEC logistics investments in Pakistan by China to study and discuss its legal and policy based perspectives. This part highlights particular laws and brief facts about their significance for bilateral trade. It includes all domestic transport laws in Pakistan, bilateral treaties with China, international laws and conventions on transport to whom Pakistan has ratified. This discussion will pave the way of this research to find out the deficiencies regarding harmonization and efficiency of the current Pakistan legal regime (Pakistan International Chamber of Commerce, 2015).

1) Pakistan Domestic road transport and logistics laws

Motor Vehicle Ordinance, 1965

$>$ National Highways Safety Ordinance, 2000

Nation highways authority Act, 1991

Brief facts about above mentioned laws

- These laws can only fulfill the demand of domestic over land logistics.

- They are out dated as not amended ever to fulfill the criteria of advance trade facility.

- These laws can only cover the registration of vehicles, driving rules, safety rules, highway violations and no link with international transportation management.

2) United Nations Conventions on Road Laws on trade facilitation

- Convention on the Temporary Importation of Private Road Vehicles, 1957 (both China and Pakistan have not ratified)

$>$ Protocol to convention in international carriage of goods by road, 1956 (China has not ratified, Pakistan just adhere February 2017)

> Convention on Temporary Importation of Commercial Road Vehicle, 1956 (both China and Pakistan have not ratified)

$>$ Convention on the taxation of road vehicles, 1956 (both China and Pakistan have not ratified)

Convention on the Contract for the International Carriage of Goods by Road

$>$ Convention on road traffic, 1949 (both China and Pakistan have not ratified) Brief Facts about mentioned laws

- Both the countries have not ratified all the United Nations conventions except Pakistan has one only.

- All those conventions do not meet the requirements of latest over land trade 
and transit trends as most of the countries adopt their own criteria which are set through economic corridors for better logistics investment.

- These conventions do not cover every logistics arrangement aspects. In present trade models; transit, customs, storage investment has key role to play.

- These conventions do not carry harmonization and regional integration principles.

3) Pakistan-China Agreements on Movement of Goods \& Passengers (Treaties)

Agreement between Pakistan \& China Concerning International Road Transport

$>$ Implementation rules of agreement between Pakistan and China on international road transport

$>$ Protocol on Agreement between Pakistan \& China Concerning International road transport

Brief Facts about mentioned treaties between China and Pakistan.

- These treaties only cover issuance of license, carriage of goods, conditions regarding permits.

- These treaties are not fully equipped to welcome huge flow of traffic and goods on border.

- These treaties are not in line with present model of CPEC.

- Pakistan has already amended some important laws on demand of China e.g. Special economic zone Act, Competition law and land acquisition rules. Without entering into bilateral logistics arrangement, China may ask again Pakistan to amend such bilateral agreements for his own benefit.

- Apart from CPEC, there is strong system of regionalism persist. It also demands to enter into multilateral agreements as to only depend upon bilateral agreements.

- Due to rapid growth of socio-economic progress in the area, Pakistan must get ready for future international political economy competition and it required region wise trade agreements.

4) Applicable law on CPEC for logistics investment in Pakistan

Free Trade agreement between China and Pakistan, 2006

$>$ World Trade Organization, 1995 with context to GATT 1948

$>$ General agreement on Trade and Tariff, GATT 1948

- Technical Barriers to Trade (TBT) and Trade Facilitation Agreements (TFA) under WTO

\section{Points of Conflicts in over Land Logistics Investment and Applicable Laws}

1) Free Trade Agreement (FTA)

While referring to FTA as applicable law, it only provides rules relating to origin of goods which itself very limited scope of FTA (Chapter Four. articles 12 24). While dealing with bilateral and further multilateral agreement like CPEC, it has many deficiencies in terms of transportation rights, issuance of visas, nature 
of stay of vehicle operators, customs clearance, and inspection of goods, storage rules. Free trade agreement basically has developed for concessionary rights e.g. reduce tariff, lower custom duty, and import/export tax exemptions (as mentioned in its preamble). It also cover principle of MFN and National treatment rules but very few towards cross border logistic investments.

2) World Trade Organization

In CPEC, logistics commitments are only from China Pakistan Free Trade Agreement. As to commitments in WTO, both parties shall follow them. These commitments only apply to Foreign Service provider gets market access in another country. If foreign investor sets up joint venture in another country, these commitments do not apply. The disciplines follow host countries' Negative List of Foreign Investment, company law and relevant regulations.

In border areas between China and Pakistan, in Chinese side is Xinjiang Province, a highly autonomy province of China, so there are a number of special logistics regulations apply. These special regulations cannot be shown from official website. These boarder measures are allowed by WTO GATT 1994.

Beyond these laws and regulations, under CPEC, due to different investment agreements have signed already, and corresponding logistics arrangement maybe are arranged already. These special arrangements may get through interviews of different investors, because these investment agreements are business secret.

Along with above mentioned future challenges which may come up with CPEC logistics investment in Pakistan, there is some relevant issues which obstruct the logistics investment. They are choice of international logistics rules, allotment of licence and priority based companies for cargo, criteria of inspection of goods on sides, storage arrangements, issuance of visas and stay of cargo employees, toll charges and right of movement of transport holders. These are all issues relevant with Chinese logistics investment in Pakistan under CPEC, therefore has to be considered by Pakistan closely and wisely.

\section{CPEC Investment and Future Challenges for Pakistan}

There is a lot criticism over transparency issues of CPEC. Therefore, looking in to the legal nature of the CPEC arrangement in Pakistan is complicated. This is for the reason that data in this regard is difficult to ascertain. The concerned department in the Ministry of Planning, Development \& Reform deals with CPEC has restricted original documents on its website and therefore access for all the concerned arrangements as between China and Pakistan have been hard to go through. Furthermore it is the press in Pakistan who has noticed this fact about the deficiency and non availability of original documents related to CPEC initiative and further implementation. Through available data on including print and electronic media depicts that CPEC arrangements are mainly based upon Memorandums of Understanding. Approximately 51 Memorandums of Understanding have been signed between Pakistan and China and most of these are concluded between Pakistan and Chinese firms. Therefore it appears compli- 
cated and hard to find out relevant information in connection to applicable laws in that context. In the absence of such laws, both the countries have arranged to go further with Free Trade Agreement (2006) as well as WTO-GATT \& GATS conventions. Pakistan right from its membership of WTO is not completely focused and liberalized its trade policies in domestic with connection to bilateral commitments. To achieve better results from CPEC logistics investment and relying on WTO commitments, Pakistan is in dire need to re evaluate WTO trade specific requirements and specific commitments both the countries have made. For example, most favoured nation (MFN) principle under article 1 of GATT, article 2 of GATS and article 4 of TRIPS agreement is very relevant here for discussion. As a matter of foreign investment in Pakistan, it shall be regulated by relevant investment agreements with concerned countries on a most favoured nation basis (The Pakistan Business Council, 2013). Therefore in CPEC logistics investment the facilities and exemptions by Pakistan to Chinese investors are required to analyze closely as these may also claimed by non-Chinese foreign investors in Pakistan under the most favoured nation standard. In the same situation it is also required to address the position of Chinese private investors and state owned companies are both in the same category to be dealt under the principle of most favoured nation?

There is series of discussions and debates within Pakistan about CPEC's logistics investment domestic aspects but less has discussed in international approach. It has been discussed above that CPEC logistics investment frame work laid down on different agreements entered and enforced between China and $\mathrm{Pa}$ kistan. For the enforcement of treaty or international agreement in Pakistan, further federal legislation domestically is prerequisite for the enforcement of concerned treaty. For this purpose it is matter of great importance to find out how many treaties between China and Pakistan on logistics investment are ratified through federal legislation domestically? According to the Vienna Convention on the Law of Treaties, 1969 "any agreement governed by international law qualifies as an enforceable treaty when it is expressed in writing between the states those intend to commit themselves" (Vienna Convention, Article 14). It means for the sake of arguments MOUs signed between China and Pakistan are presumed to be enforceable agreements under the definition of Vienna Convention and further need to be incorporated in domestic legal system through federal legislation. However none of these MOUs is in the process of ratification through federal legislation due to non consensus and conflicts of interests between federal and provincial state units. In the same way CPEC logistics investments deals with not only federal jurisdiction but also all the provincial stakes and benefits are involved in it. To build consensus and make them closer, Council of Common interests is the representative body for this purpose. The policy and guidelines over CPEC logistics investment is provided by this institute. In ongoing situation different conflicts pertaining route priority, funds allocation, transparency, lack of communication, projects handling are exist between federation 
and provincial governments. This uncertain situation may result in unnecessary delay and hindrance in the way of successful logistics investment and its enforcement. Under article 14 of Vienna convention, Pakistan should only enter into treaties for which it has the requisite domestic political consensus and after it has created the necessary political and legal space for their execution. Once it enters into a treaty, it is bound to make it part of domestic law and to expeditiously implement its obligations. At present, the politics of federalism and the absence of domestic legal reordering and preparedness has created a strong possibility of CPEC projects being subjected to unscheduled delays, even possible cancellations, exposing Pakistan to liability for violating its international commitments. There is no strong evidence of malpractice by Chinese companies overseas; however, in CPEC proposed plan and framework, the elements of corporate governance and social responsibility seems to be neglected which may raise objections in future. Furthermore, these areas should be dealt with more attention and priority based as the Pakistan on the other hand has weak transparency level and not properly developed over corporate governance issues (Campbell, 2009).

In the light of above discussion relating to domestic and international legal and policy challenges, this may cause and generate following problems which are required to be addressed sooner or later.

- China urged to push his own labor during all logistics construction projects in Pakistan. Meanwhile labor from Pakistan willfully do not use. This self projected rule from China causes destructive impacts on labor sector of $\mathrm{Pa}$ kistan (Qasim, 2016).

- Due to social and political dilemma in Pakistan, the manufacturing and exports units are enforced to be shut down. In this situation, CPEC can only be a corridor of connectivity for Pakistan rather than economic corridor (Economic Advisor's Wing, Finance Division, Government of Pakistan, Islamabad, 2015).

- In comparison between China and Pakistan for fast socio-economic progress, China is well ahead. This difference will create Hegemonic situation by the China for Pakistan.

- China has more concern with connectivity throughout Middle East, Africa, Europe, and Central Asia as per Chinese vision paper. Therefore more attention is given to connectivity contracts as compare to investment and trade arrangements in Pakistan (Ebrahim, 2016).

- Most importantly, some neighboring countries of Pakistan have raised sovereignty, strategically, movement of ammunition and weapons, right to use of passage issues over CPEC. This is more in relationship with India. Hence to be addressed wisely and proficiently (Nazki, 2017).

- Recently some investment related contracts like erection of special economic zones and construction of Gwadar port willfully handed over to Chinese companies only. This has been done without offering and inviting such contracts 
to other competitors in the market. This act do not adhere market competition and bidding rules and may challenged in Pakistani courts (Iqbal, 2017).

- It has been noted and observed through past examples that Chinese companies during international agreements were failed to compliance principles of corporate social responsibility, human rights and environment protection related rights in host countries. These are also not adhered in the Chinese visionary paper or in any code under CPEC projects. Therefore Pakistan must get ready to overcome these issues (Zadek, Simon, Chen et al., 2009).

\section{Suggestions and Recommendations}

It is evident from above discussion that CPEC at its early stage must be a successful transport corridor to fulfil the needs as economic corridor at later stage. Furthermore it is also mentioned that CPEC will become a regional corridor due to its unique geographical and investment situation. Pakistan comparatively with China, a slow and weak economy does not keep its pace with the changing situation in the region with regard to Chinese ambitions. For the maximum utility and to safeguard its interest at a broader level, Pakistan is an urgent need to prioritize transport corridor projects, and enhance regional integration through regional transit in a time-bound manner. In Pakistan, the lack of transport and transit facilities is a major reason for the low level of economic exchanges. In particular, the task ahead for Pakistan is to revive transportation networks and establish region-wide intermodal transport and transit to reduce transportation costs (Shoaib, 2009). In CPEC, China and Pakistan and other future partners should have their own regional transport and transit arrangement, or all the countries of the region should accede to existing international conventions.

This research paper is aimed to provide comprehensive frame work of legal rules and regulations for logistics investment in perspective of Pakistan. Furthermore, for the infrastructure of CPEC transport network to function throughout the region effectively, the necessary soft infrastructure, such as relevant rules, regulations, and standards, has to be in place. Rules, regulations, and standards must meet a common regional benchmark, or more preferably an international one. The participating countries need to formulate and agree on a harmonized set of rules, regulations, and standards, similar to the Cross- Border Transport Agreement (CBTA) adopted by the Greater Mekong Sub region (GMS) countries. A CBTA is an important step toward harmonizing the software related to cross-border infrastructure use (Edmonds \& Fujimura, 2015).

Furthermore, to make CPEC effective at the part of Pakistan, it needs to incorporate its provisions into their national laws, regulations, and standards. Moreover there is the requirement for higher-level coordination among the local stakeholders and agencies concerned, such as transport, customs, immigration, and quarantine authorities. At the same time, the capacity of national institutions has to be enhanced for effective implementation of these agreements. There is also the need for a uniform or compatible standard for developing cross-border 
transport networks that are beneficial to all stakeholders. The establishment of an efficient management system and capacity building to look after the harmonization of standards would pave the way to achieving regional connectivity. This would ultimately help achieve single-stop and single-window customs offices across China Pakistan economic corridor (Maher, Hussain, \& Ahmad, 2014).

While focusing on up gradation of transport and transit rules and regulations for best utilization of CPEC, this research will further lead to the experiences of Europe and Latin America, where cross-border infrastructure is comparatively developed, and to a lesser extent, Africa, where the development of cross-border infrastructure has taken a new shape, suggest that harmonized and advanced regional cooperation in logistics investment promotes greater prosperity and stability for participating countries. A major success factor in the ability to build regional initiatives that are based on a shared strategic vision, as seen in the Initiative for the Integration of Regional Infrastructure in South America (IIRSA) (IIRSA, 2009). From above mentioned facts, it is highly desirable that CPEC transport and logistics investment in Pakistan has to be much stronger to address regional infrastructure needs, and to cultivate, enabling institutions and policies best favoured to Pakistan in particular and CPEC member countries in general.

\section{Conclusion}

Since China has broader and extensive goals in CPEC initiative, among others to give Chinese companies global market access and to take full advantage of greater regional connectivity, Pakistan has to be allowed to obtain wholesome benefits and not to be restricted only to corridor of connectivity. Furthermore, transport and logistics undeniably plays critical role in every country's economic development. Without well-developed transport infrastructure and logistics industry in Pakistan, CPEC will not be materialised. However, this sector was not sufficiently covered by the bilateral treaties between China and Pakistan. At least up to date there is no a framework agreement to deal with transport and logistics arrangement under CPEC.

In the light of the above discussion and arguments, it can be concluded that sustainable economic development of Pakistan is primarily achievable through strong and comprehensive socio legal framework of logistics investment both domestically and region wise. Furthermore, Pakistan's much needed enhanced export competitiveness also relied on the well-organized structure of the sector. To achieve the targets of sustainable economic growth and worldwide export challenges, Pakistan government has already initiated economic trade corridor program (ETCP) to revise and generate a comprehensive transport mechanism of ports, rail, road and oil \& gas pipelines. This will help make Pakistan more competitive economically, and also pave the way of fruitful logistics investment through China Pakistan Economic Corridor. To gain this momentum of logistics investment and to get desired results from CPEC, a highly competitive and 
effective set of legal rules and regulations is direly required which does not only comprised on domestic legal regime but also provide transnational harmonized and integrated legal structure. Moreover, it is vastly foreseeable that CPEC not only will remain between China and Pakistan but also welcome other economic players in the region on an immense level. Moreover, public private partnership (PPP) strategy can play significant role in the development and success of CPEC logistics investment in Pakistan. But for this move, government of Pakistan is required to provide a clear legal and administrative set of rules and also minimize the barriers in the way of successful public private partnership regime.

For the purpose of achieving high results from CPEC investment, both China and Pakistan should develop efficient road and logistics infrastructure and also adopt innovative software rules and regulations system to achieve the goal of regional economic integration through trade. In this regard, best practice may be seen and adopted from GMS (Greater Mekong Sub region) economic corridor, CAREC (Central Asian Regional Economic Corridor), African corridors like Cambodia and Lao Peoples' Democratic Republic economic corridor, Walvis Bay Corridor (Namibia, Zambia, Zimbabwe, Botswana, Angola and South Africa and indirectly to the Democratic Republic of Congo), TRACECA (Transport Corridor Europe, Caucasus, Asia), TEN (The Pan European Transport Network), NAFTA (North American Free Trade Agreement).

This research further concludes that the construction of CPEC is an important consensus reached by the leaders of China and Pakistan. It will optimize the trade and energy cooperation between China and Pakistan and benefit over three billion people in China, South Asia and Middle East. CPEC realizes the new realities of global and regional politics by cultivating a more systematic, up-graded and need-based interaction for socio-economic, industrial, energy and trade development.

\section{References}

Associated Press of Pakistan (2017). CPEC Making Significant Progress: Report. https://www.app.com.pk/cpec-making-significant-progress-report/

Benish, S. (2013). Rejuvenating Pakistan's Standing: Benefitting from China's Rise. NDU Monograph, 4, 4-32.

Campbell, D. (2009). International Protection of Foreign Investment (2nd ed.). Yorkhill Law Publishing.

China Pakistan Economic Corridor Council (2014). JJC OF CPEC $3^{\text {rd }}$ Meeting Held in Beijing. http://www.c-pecc.com/enindex_en.html

China-Pakistan Institute (2009). Realizing the Future Collectively. http://www.pakistan-china.com/pci-about.php\#Aboutus

Ebrahim, Z. T. (2016). China Pakistan Economic Corridor: A Boon for the Economy, a Bane for Locals. https://www.dawn.com/news/1236159

Economic Advisor's Wing, Finance Division, Government of Pakistan, Islamabad (2015). Pakistan Economic Survey, 2014-2015. www.finance.gov.pk/survey/chapters_15/Highlights.pdf 
Edmonds, C., \& Fujimura, M. (2015). Road Infrastructure and Regional Economic Integration: Evidence from the Mekong. In D. H. Brooks, \& J. Menon (Eds.), Infrastructure and Trade in Asia (pp. 28-53). Cheltenham: Edward Elgar.

Government of Pakistan, Trade \& Development Authority of Pakistan (2016). Rules of Origin for the China-Pakistan Free Trade Area.

http://www.tdap.gov.pk/pdf/Annex-II_PK-CN_FTA.pdf

IIRSA (2009). Initiatives for the Integration of regional South American Infrastructure. IIRSA Project Portfolio 2008. Buenos Aires. http://www.iirsa.org/bancomedios/documentos\%20PDF/doc_cartera_2008_eng.pdf

Iqbal, W. (2017). SEZs: China Seeks Extra Incentives. http://www.epaper.brecorder.com/2017/07/14/1-page/888694-news.html

Khan, M. (2015). Analysis: Trade through Land Routes. The Dawn. https://www.dawn.com/news/1202356

Maher, M. Y., Zakir, H., \& Nisar, A. (2014). Economic Evaluation of Foreign Direct Investment in Pakistan. Pakistan Economic and Social Review, 46, 37-56.

Mateen, I. (2015). CPEC: Economic Corridor in Focus as Pakistan, China Sign 51 MOUs. The Dawn. http://www.dawn.com/news/1177109

Ministry of Finance (2014). http://www.finance.gov.pk/survey_1415.html

Ministry of Foreign Affairs, Government of Pakistan (2013). Joint Statement Deepening Comprehensive Strategic Cooperation between the People's Republic of China and the Islamic Republic of Pakistan.

https:/policy.asiapacificenergy.org/sites/default/files/The\%20Joint\%20Statement\%20of\% 20the\%20People\%27s\%20Republic\%20of\%20China\%20and\%20the\%20Islamic\%20Repub lic\%20of\%20Pakistan\%20on\%20Deepening\%20the\%20Overall\%20Strategic\%20Cooper ation\%20between\%20the\%20Two\%20Countries.docx

Ministry of Planning, Development and Reform (2015). Pakistan Economic Survey 2015-2016. Vision Pakistan. http://www.pc.gov.pk .

Ministry of Ports and Shipping. Gwadar Port Authority (2015) Gwadar Port and CPEC: A Presentation to the Parliamentary Committee on CPEC. November 28.

Muhammad, S. I., Qi, X., \& Hamza, A. (2016). One Belt One Road: Does China-Pakistan Economic Corridor Benefit for Pakistan's Economy"? Journal of Economics and Sustainable Developments, 6, 200-207.

Nazki, S. M. (2017). Kashmir's Reckoning with the Implications of the China-Pakistan Economic Corridor.

https://thediplomat.com/2017/03/kashmirs-reckoning-with-the-implications-of-the-ch ina-pakistan-economic-corridor/

Pakistan International Chamber of Commerce (PICC) (2015). Pakistan Trade Facilitation Portal. National and International Laws.

http://www.ptfp.com.pk/Transport/National/national-transport-maritime-laws/Maritime

Qasim, M. (2016). How Chinese Money Will Transform Pakistan.

https://www.dawn.com/news/1288391

Rizvi, H. A. (2015). The China-Pakistan Economic Corridor: Regional Cooperation and Socio-Economic Development.

http://issi.org.pk/wp-content/uploads/2015/12/Hasan-Askari-Rizvi_3435_SS_41_20142 015.pdf

Shoaib, M. et al. (2009). Trade Liberation and Regional Disparities in Pakistan (p. 16). New York, NY: Routledge Publishers.

Small, A. (2015). Pakistan Lands \$46 Billion Investment from China. CNN News. 
http://money.cnn.com/2015/04/20/news/economy/pakistan-china-aid-infrastucture/in dex.html

The Pakistan Business Council (2013). Preliminary Study on Pakistan and China Trade Partnership Post FTA.

http://www.pbc.org.pk/assets/pdf/21-Oct_Pakistan_China_Trade_Study_2013.pdf

Vickerman, R. (2002). Restructuring of Transportation Networks. In G. Atalik, \& M. M. Fischer (Eds.), Regional Development Reconsidered. Berlin: Springer.

https://doi.org/10.1007/978-3-642-56194-8_8

Vienna Convention on Law of Treaties 1969, Article 14.

Zadek, S., Chen, X., Li, Z., Jia, T., Zhou, Y., Kelly, Y., Maya, F., \& Guy, M. (2009). Responsible Business in Africa: Chinese Business Leaders' Perspectives on Performance and Enhancement Opportunities. Accountability and the Enterprise Research Institute, Development Research Centre of the State Council of P.R. China (DRC-ERI).

http://www.accountability21.net

Zafar, H. (2015). The Corridor of Hope. Daily Times. http://www.dailytimes.com.pk/business/25-Jul-2015/the-corridor-of-hope 